\title{
Elinikäisen oppijan narratiivit: aikuiskoulutus elämän kuteena
}

\author{
Elämänkerralliset aineistot mahdollistavat ihmisen toiminnan \\ tarkastelun pitkittäisesti ja kertomuksenomaisesti. Voidaan kerätä \\ tietoa ihmisten elämänkulusta ilman poikkileikkaustutkimusten \\ rajoituksia. Seuraavassa artikkelissa kohteina ovat \\ koulutuselämänkerrat, ts. elämänkertomuksissa, joissa pääpaino \\ on kertojan koulutuskokemuksissa. Kuvattavan tutkimuksen \\ aineistona käytetyt elämänkertomukset tuotettiin \\ koulutukselliin ja tutkimukselliin tarkoituksiin.
}

\begin{abstract}
Elämänkerrallinen lähestymistapa on viime vuosina muodostunut yhä keskeisemmäksi sekä eurooppalaisessa aikuiskoulutustutkimuksessa että aikuiskoulutuksen välineenä (kts. Alheit ym. 1995). Suomessa elämänkerrallinen tutkimus koulutustutkimuksessa on viime vuosiin saakka ollut vähäistä. Tilanne on kuitenkin muuttunut, mistä selkeimpänä yksittäisenä ilmauksena on Ari Antikaisen johtama 'K oulutuksen merkitystä etsimässä' -tutkimusprojekti lukuisine eri foorumeilla julkaistuine raportteineen (kts. erityisesti Antikainen ym. 1996, Antikainen \& Huotelin 1996).
\end{abstract}

E lämänkerralliset aineistot mahdollistavat ihmisen toiminnan tarkastelun pitkittäisesti ja narratiivisesti. Tämä tarkoittaa sitä, että voidaan kerätä tietoa inmisten elämänkulusta ilman poikkileikkaustutkimusten, kuten kyselyjen, rajoituksia. Luonnollisesti myös elämänkertatutkimuksella on rajoituksensa ja ongelmansa. M itä ongelmat kulloinkin ovat, riippuu paljolti tutkijan lähestymistavasta; onko hän ensisijaisesti kiinnostunut aineistostaan objektiivisen todellisuuden kuvana, väylänä ihmisten tietoisuuteen vai kulttuuristen kielenkäytön tapojen edustajana. Nämä kolme lähestymista- paa eivät välttämättä sulje toisiaan pois, vaikka on selvää, että esimerkiksi inmisen toimintaa hahmotettaessa tekstinä taka-alalle jää toiminnan biologinen ja psykologinen perusta (Jussila 1992).

Eurooppalaista sosiologista elämänkertatutkimusta luonnehtivat erilaiset lähestymistavat ja tutkimustehtävät. Huomiota ei ole kiinnitetty vain mikrotasolle, vaan erilaiset makrososiologiset kysymykset ovat myös olleet mukana (Bertaux 1983, 6-10, Bertaux \& K ohli 1984). Rakenteellisten tekijöiden tarkastelu elämänkertojen kautta nojaa huomioon, että yksilön elämänkulku ei noudata pelkästään omaa logiikkaansa, vaan sen muotoutuminen on osaltaan seurausta inmiselle ulkoisista yhteiskuntarakenteellisista ehdoista. Niinpä ihmisten tyypilliset elämänkulut ja jonkin insituution - vaikkapa koulun - tärkeys siinä vaihtelevatkin huomattavasti eri yhteiskuntien välillä (Pallas 1993).

Elämänkertojen avulla voidaan siis hankkia tietoa siitä, mikä tiettyjen yhteiskunnallisten olosuhteiden vallitessa on tyypillistä. $\mathrm{N}$ iiden avulla voidaan tutkia myös henkilöitä, jotka syystä tai toisesta poikkeavat tavanomaisesta. Standar- 
disoitu elämänkulku on aina abstrakti kuvaus. Y ksittäisten inmisten tasolla elämässä on paljon vaihtelua; inminen ei passiivisesti toimi niin kuin rakenteet määräävät (esimerkiksi Meyer 1986, 209). Tässäkin tutkimuksessa molemmat puolet, sekä elämänkulun institutionaalisuus että yksilöllisyys, tulevat esiin. Tutkituissa elämänkertomuksissa näyttäytyy se, kuinka tietyt yksilön kannalta ulkoiset instituutiot ja yhteiskunnalliset olosuhteet vaikuttavat ihmisten elämänkulkuun, mutta inmisten ratkaisut kuitenkin ovat yksilöllisiä.

Elämänkertatutkimuksessa jako yksilöön ja yhteiskuntaan tuntuukin toisinaan hieman keinotekoiselta; elämänkertomuksessa molemmat ovat yhteenkietoutuneena. K onstruktionistisen ajattelun valossa tämä onkin aivan luonnollista; instituutioiden muodostamien sosiaalisten rakenteiden katsotaan olevan olemassa vain yksilöiden tietoisuuden ja merkityksenannon kautta. K enneth G ergen $(1991,264)$ toteaa, että inmisen autdoiografia on kaikkea muuta kuin autonominen, pikemminkin se on sosidbiografia, niin vahvasti elämänkertomuksessa on myös yhteiskunta mukana. K ertoessaan elämästään inmiset yhtä aikaa (1) tekevät selkoa tapahtumista, (2) tekevät selkoa itsestään kerto essaan olosuhteistaan ja (3) tekevät selkoa vallinneista sosiaalisista suhteista (McCall 1985, 176177).

K ertomukset, myös elämänkertomukset, tuotetaan aina jotain tai joitain tarkoituksia varten. Tässä tutkimuksessa aineistona käytetyt elämänkertomukset tuotettiin koulutukselliin ja tutkimukselliin tarkoituksiin. Tämä luonnollisesti vaikutti niiden sisältöön. Vaikka olisi kysymys samasta elämästä, kertomus voi vaihdella huomattavastikin. Eri tilanteissa henkilö poimii elämänkerrallisesta muististaan eri asioita. $\mathrm{H}$ än myös saattaa tulkita elämänsä tapahtumia eri tavoin (K ohli 1983, 65). Elämänkertomus on valinnan ja tulkinnan sävyttämä. $\mathrm{N}$ iinpä voidaankin K nudsenin $(1990,122)$ tapaan väittää, että elämänkertomus ei ole suora kertomus henkilön elämästä, vaan itsensä esittämisen, toimien oikeuttamisen ja tulevaisuuden projektioiden strategia.
Elämänkertomukset myös noudattavat kulttuurisia kerronnan ja kielenkäytön konventioita. Gergen \& G ergen $(1988,28)$ toteavat, että kulttuurissa vallitsevien kertomustyyppien määrää ei voida rajata mihinkään tiettyyn, mutta tietyssä kulttuurissa tietyn tyyppiset kertomukset ovat yleisempiä ja todennäköisempiä kuin toiset. N iinpä tässäkin aineistona olevat kertomukset kuvaavat sitä, millä tavoin kulttuurissa puhutaan koulutuksesta osana ihmisen elämänkulkua. Eri sukupolvea edustavien kirjoitukset yleensä vaihtelevat $\mathrm{mm}$. siinä, missä määrin kirjoitukset pitäytyvät kronologiaan tai korostavat jatkuvuutta ja yhtenäisyyttä (Vilkko 1988).

\section{Aineisto}

Aineistona käytetään kuuden kasvatustieteen ja yhden aikuiskasvatuksen opiskelijan kirjoittamia elämänkertoja ja heidän käymiään pienryhmäkeskusteluja. K irjoitustehtävä ja keskustelut olivat osa cum laude approbaturin 'kvalitatiivinen tutkimus kasvatustieteissä' -opintojakson harjoituksia avoimessa yliopistossa vuonna 1995. O pintojakson yleisenä tavoitteena oli perehdyttää kvalitatiivisen tutkimuksen perusteisiin ja menetelmiin.

Avoimen yliopiston opiskelijat eivät välttämättä hae ystävyyssuhteita opiskelunsa kautta ( $\mathrm{N}$ ieminen 1990,126). Harjoitusten alkaessa olisi ollut käytännössä vaikeaa ja eettisesti kyseenalaista "pakottaa" opiskelijat kertomaan ja kirjoittamaan toisilleen elämästään, vaikka alussa selvitettiinkin kirjoitusten käyttö ja tarkoitus. O piskelijat saivat valita kahden toimintamuo-don välillä: a) analysoida aikaisemmin toiselta opiskelijaryhmältä kerättyjä oppimispäiväkirjoja, tai b) kirjoittaa omaa elämänkertaa ja tarkastella omaa ja toisten opiskelijoiden kirjoituksia tutkimuksellisena aineistona. 19 opiskelijasta seitsemän valitsi elämänkerran kirjoittamisen. H arjoitusryhmiä oli kaksi; toisesta oli mukana viisi ja toisesta kaksi opiskelijaa. Valintaa tehdessään opiskelijoilta kysyttiin lupa käyttää kirjoituksia aineistona artikkelissa ja toisaalta lupa ottaa nauhalle pienryhmäkeskustelut. (K s. viite 1 sivu 302) 
K irjoitusprosessin aktivoituminen tapahtui ryhmätyöskentelyssä, jossa opiskelijat ennen kirjoittamista etsivät yhteistä rajausta kirjoituksilleen. Tavanomaisesta elämänkerran kirjoittamisesta poiketen opiskelijat eivät kirjoittaneet vapaasti elämästään, vaan päätyivät kirjoittamaan koulutuksellisen elämänkerran. K irjoitusten valmistuttua opiskelijat saivat tehtäväkseen keskustella kirjoitusten yhtäläisyyksiä ja eroja, pohtia kenelle he olivat kirjoittaneet ja miten se mahdollisesti näkyy kirjoituksessa, pohtia mahdollisia tutkimustehtäviä, ja tehdä aineiston analyysisuunnitelmaa.

0 piskelijoiden kirjalliset tuotokset olivat laajuudeltaan 3-5 sivua. $\mathrm{N}$ auhoitetut keskustelut tuottivat 27 sivua aineistoa. K eskusteluja käytetään tässä artikkelissa kahdessa funktiossa: (a) ne ovat lisäaineistona kirjoitusten rinnalla, (b) niitä käytetään lähteenä pohdittaessa elämänkertojen kirjoittamista opetusmuotona. Elämänkerran kirjoittaminen tuottaa muussa yhteydessä usein laajemman aineiston. Esimerkiksi Tigerstedtin (1984) tutkimuksessa opiskelijoiden elämänkerrat olivat keskimäärin 26 sivua; vaihtelu viisi sivusta yli sataan.

\section{Elämänkerran kirjoittaminen koulutuksessa}

K irjoittaminen kuuluu olennaisesti yliopistoopiskeluun. K irjoittamista oppimisen välineenä voi tarkastella erityisesti konstruktivistisen op-pimiskäsityksen lähtökohdista (Tynjälä 1996). K irjoittamista käytetään myös tavoitteellisesti välineenä, jonka avulla opiskelijat Iöytävät 'omaa ääntänsä' ja ymmärtävät historiaansa ja subjektiutensa syntyä. H enkilökohtaisten kertomusten kirjoittaminen ja niiden analysointi kuuluvatkin kriittisen pedagogiikan ja feministisen pedagogiikan käytänteihin. (Lindroos 1995.) O masta elämästä kirjoittaminen on ongelmanratkaisua opiskelijan tuottaessa, eritellessä, yhdistellessä ja jäsennellessä kokemuksiaan, tunteitaan, tietoaan ja mielipiteitään (kts. Linnakylä et.al.1988,10). Toiminta tukee itsereflektiota ja koulutuksen yhteydessä prosessissa on tukena ohjausta tämänsuuntaisiin tavoitteisiin.

Elämänkerran kirjoittaminen voidaan organisoida opetuksen yhteydessä Dominicén (1995) mukaan esimerkiksi seuraavasti:

(1) O piskelijat rakentavat ensin suullisesti kertomustaan elämästään. Tätä voidaan verrata prosessikirjoittamisen luonnosteluvaiheeseen, jossa kirjoittaja antaa ajatustensa virrata (kts. Linnakylä et.al.1988,11).

(2) Suullista kertomusta seuraa keskustelu, jonka tarkoituksena on laajentaa ja tarkentaa esitettyä kertomusta. Muiden opiskelijoiden tehtävänä on kysymyksillään ja kommenteillaan auttaa esittäjää selkeyttämään ajatuksiaan.

(3) O piskelijat tuottavat kirjallisen tuotoksen, joka on muodollisempi verrattuna suulliseen.

(4) Kirjoituksia tarkastellaan lopuksi pienryhmässä.

(Dominicé 1995.)

Tutkimuksessamme opiskelijat eivät kokeneet vaikeana kirjoitustehtäväänsä, mikä tulee esille nauhoitettuja keskusteluja tarkastellessa: "E i ollu kovin hankala tehtävä", "Itsestään kirjoittaa ihan mielellään."

K irjoitusten käyttö ja tarkoitus oli selvitetty kirjoitusprosessin alussa, mikä luonnollisesti suuntasi prosessia, vaikka se ei ollut välttämättä kovin tietoista.

"Se on kylä minusta aika sevä juttu, että miksi kirjoitettiin, emmä miettiny sitä kylä kummemmin siinä tilanteessa, että kenelle kirjaitan tai miksi kirjoitan."

“..enkä myöskään ajatelut, etä kenele kirjoitin, että en seä pitkäsäärelle enkä mille kään kuvitelulle ja miksi kirjaitettiin, niin en mää sitäkään tässä ajatellu, etä tästä jotain analysaintia tai muta, että sen vaan kirjaitti ku tiesi, että se piti tehdä."

K irjoitusprosessissa tekemiään valintojaan (mitä kirjoittaa, mitä ei, miten) opiskelijat kuvaavat vähäisiksi alkaessaan keskustella asiasta, mutta keskustelun edetessä osa tehdyistä valin- 
noista selkeytyi.

"En mä midestäni tehnyt mitään valintoja, että ainut mitä mä tossa huomasin niin di, että sellasen valinnan mä oon tehnyt niinku tiedostamatta, että ylẹnsä ne mitä mulla di, tơa niin, ne di lähinnä tähän kouluun, taikka siis työhön liittyvä koulutuksia. (...) Sit mä din jättäny ne kaikki muut niinku joogat ja pienet kidiqpinnot mitä tämmösiä kaikkia nyt on niin ne oli sitten jääny pois, kuitenki kun ne varsinaisesti tähän vaikuttanu. (...) Mut että itseasiassa jäi kauheesti poiskin kun mä huomasin, että mä din siuthuomautuksiin laittanu kaiken näköstä ja si ne jäikin pois, just näitä tämmösiä niinku pohdintoja näistä syistä ja muista."

K eskustelut osoittavat, että omaa kirjoitusta arvioi eri tavoin luettuaan toisten kirjoituksia. Aineisto vahvistaa sitä, että samasta elämästä voidaan kirjoittaa useita, erilaisia kertomuksia.

"Me puhuttiin täs alussa, että ku di lukenu muiden, niin tuli semmonen do, että mäkin disin voinut laittaa niin tai näin tai..."

$\mathrm{K}$ asvatustieteiden opiskelussa omien elämänkertojen kirjoittaminen ja analysointi on oiva lähtökohta koulutus- ja oppimisteemojen käsittelyyn. Elämänkerran kirjoittamisen ja kirjoituksien tarkastelun kautta nousevat esiin myös tutkimusprosessiin liittyvät olennaiset kysymykset. (D ominicé 1995.) Teorian käyttö ja merkitys aineiston analysoinnissa, kvalitatiiviseen tutkimusprosessiin sisältyvien valintatilanteiden runsaus, aineiston laajuuden/niukkuuden ja luokittelun problemaattisuus, erilaisten tutkimusmenetelmien yhdistämisen mahdollisuus sekä tutkimusmenetelmän eettinen oikeutus, olivat aiheita, joita keskusteluissa käsiteltiin.

E lämänkerran kirjoittamista tai vastaavanlaista opetusmuotoa käyttäessään opettajan tulee tunnistaa toimintaan liittyviä eettisiä kysymyksiä: missä määrin opiskelijaa voi ja tulee motivoida osallistumaan tällaiseen toimintaan, miksi opiskelijat kirjoittavat elämästään, miten kirjoituksia käytetään? Voiko opettaja olettaa opiskelijoiden olevan kriittisiä ja kykeneviä arvioimaan omia intressejään ja näkemyksiään pyrkimyksissä nivoa opiskeltavia sisältöjä avoimesti heidän muuhun elämänpiiriinsä? K ysymys, haluaisinko itse osallistua ko. toimintaan opiskelijana, auttaa ratkaisujen tekemisessä. Jos opiskelijat ja opettaja päätyvät yhteisymmärrykseen elämänkerran kirjoittamisen lähtökohdista ja tarkoituksista, kirjoitusprosessi ja sitä seuraava kirjoitusten analysointi tarjoavat pedagogisesti hedelmällisen mahdollisuuden käsitellä $\mathrm{mm}$. tutkimusprosessia.

\section{Koulutuskertomukset: elinikäisen oppijan narratiivit}

0 piskelijoiden kirjoittamia seitsemää koulutuselämänkertaa kuvataan kutakin lyhyellä luonnehdinnalla. K ertomuksia ei luontevasti voinut supistaa tyyppeihin. K aikissa keromuksissa kertoja on selkeästi koulutuksen "suurkuluttaja". K ertomuksia voi luonnehtia myös "elinikäisen oppijan mallinarratiiveiksi" edustavathan näiden kertomusten päähenkilöt esimerkiksi työvoimapolitiikan kannalta ihanteellisia tapauksia; henkilöt ovat joustavia itsensä kehittäjiä, joille kouluttautuminen työn kvalifikaatiovaatimusten muuttuessa tai ammatin vaihdon yhteydessä ei ole mikään erityinen ongelma, vaan pikemminkin haaste ja itsestäänselvyys.

Pari nimilappua, joilla seuraavassa kuvataan tiettyä tapausta olisivat päteviä kuvauksia myös kaikista muista tyypeistä: koulutus on kaikille jossain määrin pätevyyden laajentaja, samoin kuin se on kaikille sekoitus kiinnostusta ja hyödyn tavoittelua. Päällimmäinen piirre ja muista erottava tekijä tai korostus, punainen lanka, oli jokaisessa kertomuksessa kuitenkin suhteellisen helposti tunnistettavissa. E rittäin tiivistettyinä kertomukset olivat seuraavan kaltaisia:

Koulutus pätevyyden laajentajana (36-vuotias mies): Pätevyys ei tässä viittaa pelkästään ammatilliseen osaamiseen. Henkilö oli hankkinut keskiasteella tekniikan alan ammattikoulutuksen, minkä jälkeen hän oli pätevöitynyt työnantajansa koulutushierarkiassa. Työn ohella hän suoritti tutkinnon myös teknillisessä oppilaitok- 


\section{HONONENSKAШONEM}

sessa. Tämän jälkeen hän on opiskellut avoimessa yliopistossa sosiaalipsykologiaa ja aikuiskasvatusta. Kertomansa mukaan opiskelu on auttanut ymmärtämään ja hyväksymään erilaisia asioita ja antanut valinnanmahdollisuuksia työuralla. Tähtää kandidaatin tutkintoon.

Koulutus kiinnostuksen ja hyödyn sekoituksena (33-vuotias nainen): Henkilöllä on yhteiskuntatieteellinen yliopistotutkinto, jota hän ammatillisen suuntautuneisuuden sijasta opiskeli lähinnä omasta kiinnostukseksestaan. Sosiaalinen opiskeluelämä oli olennainen osa opiskelua. Tutkinnon jälkeen hän on laajentanut ammatillista pätevyyttään suorittamalla avoimessa yliopistossa arvosanoja sosiaalipolitiikassa, erityispedagogiikassa ja kasvatustieteessä. Lisäksi hän on osallistunut ammatilliseen työllisyyskoulutukseen. K ansalaisopistossa hän on suorittanut kursseja mitä erilaisimmilta aloilta. Toteaa itse, että koulutus on ollut hänelle "sekoitus mielenkiintoa ja epämääräisiä hyötynäkökohtia".

Koulutus riippuvuutena (30-vuotias nainen): E $\mathrm{i}$ vielä lukiossa ollut erityisen innostunut opiskelusta. Niinpä omien sanojensa mukaan laiskuuden ja päämäärättömyyden vuoksi ei päässyt yliopistoon. Hakeutui ammatilliseen koulutukseen puoleksi vuodeksi, minkä jälkeen haki uudelleen yliopistoon. E i päässyt. Pakollisen välivuoden aikana korotti päästötodistuksen numeroitaan ja sai tästä kipinän opiskella. Jäi koukkuun. Hakeutui kauppaopistoon, missä viihtyi ja pärjäsi hyvin. Tämän jälkeen hakeutui avoimeen yliopistoon opiskelemaan kasvatustieteen approbaturia, mistä innostui "valtavasti“. O piskeli päivisin ATK :ta työllisyyskoulutuksessa ja iltaisin kasvatustiedettä. Toteaa, että "henkisestä kehityksestä huolehti kasvatustieteen opinnot". Viihtyi tosin hyvin myös ATK opinnoissa. Tämän jälkeen jäi äitiyslomalle ja aloitti markkinoinnin approbaturin opinnot. Seuraavaksi hän meni taas työllisyyskoulutukseen, nyt yrittäjäkurssille. Aloitti kasvatustieteen cum lauden opinnot avoimessa yliopistossa. K ertoo, että tarve opiskeluun on voimakas tunne, "kun kerran aloittaa, ei pysty lopettamaan". Aikoo opiskella vielä monta vuotta ja tutkinto kasvatustieteessä on suurin ambitio.

Koulutus väylänä tietylle kentälle (45-vuotias nainen): Oli jo lukiossa kiinnostunut luokantai lastentarhanopettajan ammatista. Ei kuitenkaan päässyt opettajankoulutukseen vaan meni talouskouluun. Seuraavana vuonna pääsi ja meni opiskelemaan suomea yliopistoon, jossa suoritti tutkinnon. Tämän jälkeen haki lastentarhaseminaariin, pääsi ja suoritti lastentarhanopettajan tutkinnon. Työskenteli esikoulunopettajana ja myös ala-asteen opettajana. Jäi kuitenkin työttömäksi ja hakeutui opiskelemaan alkuopetusta sekä myöhemmin kasvatustiedettä avoimeen yliopistoon. $0 \mathrm{n}$ edelleen vailla työtä ja toteaa, että "tottumisen jälkeen työttömänä oleminen ei tunnu hullummalta kun voi sivutoimisesti opiskella ja välillä tehdä sijaisuuksia". Opiskellut myös erilaisia harrastusluonteisia aloja. Harkitsee opintojen jatkamista kasvatustieteen kandidaatiksi.

Koulutus reaktiona työelämän haasteisiin (48vuotias nainen): Ylioppilaaksi pääsyn jälkeen hän ajautui sattumalta lastentarhaan harjoittelijaksi, mikä sai hakeutumaan lastentarhaseminaariin. Ala tuntui kutsumusammatilta, vaikka valinta jälkeenpäin ajatellen näytti sattumalta. Pian valmistumisen jälkeen siirtyi vammaisten lasten esikoulun opettajaksi. Jonkin ajan päästä alkoi kokea tarvitsevansa lisäkoulutusta ja opiskeli sosiologiaa, musiikkia, ilmaisuaineita ja kasvatustiedettä. Vuodet kuluivat töissä ja omia lapsia kasvattaen ja kouluttautuminen oli vähäistä. Työpaikan pysyvyys muodostui kuitenkin epävarmaksi, mikä sai lähtemään opiskelemaan erityispedagogiikkaa, logopediaa, viittomakieltä, musiikkiterapiaa ja MPD -terapiaa. H akeutui esiluokanopettajaksi. Koska oli kuitenkin epäpätevä, alkoi hankkia koulutusta kesäyliopistossa ja suoritti kouluhallinnon arvosanan. Aloitti myös kasvatustieteen cum lauden opiskelun avoimessa yliopistossa. Työhön liittyvien asioiden lisäksi on opiskellut erilaisia asioita myös "itsensä iloksi". Mahdollisesti jatkaa kasvatustieteen opintoja pidemmälle.

Koulutus itsestäänselvyytenä (26-vuotias nai- 


\section{ARाাKस}

nen): $\mathrm{H}$ änen kertomuksessaan opiskelu on ollut "rento" asia harrastusten ja poikaystävän lomassa. Ylioppilaaksi pääsyn jälkeen meni yläasteelle historian opettajaksi, mikä oli hyvä kokemus. A sunut eri paikkakunnilla. Aloitti kauppaopiston muutettuaan poikaystävän vuoksi Tampereelle. K auppaopisto ei kuitenkaan ollut kovin hyvä kokemus. Sen jälkeen ollut töissä ja aloittanut kasvatustieteen opinnot. Tähtää nyt ala-asteen opettajaksi ja mahdollisesti myöhemmin äidinkielen opettajaksi.

Koulutus toisena mahdollisuutena (38-vuotias nainen): $K$ ertoo, kuinka nuoruuden myllerryksistä johtuen koulu alkoi jossakin vaiheessa mennä huonosti. Vanhemmat syyttivät laiskuudesta, mikä sai kapinoimaan ja kiinnittymään kaveripiiriin entistä tiukemmin. Aloitti merkantin opinnot. 0 pintojen jälkeen pääsi nuorena työelämään. Tässä vaiheessa tajusi, että voi itsekin vaikuttaa elämäänsä. H aki käsi- ja taideteollisuusoppilaitokseen ja teatterikouluun, mutta ei päässyt. Pääsi töihin mieleiselleen alalle taiteen pariin. Joutui kuitenkin vaihtamaan alaa. A loitti työn ohella ammatilliset opinnot ja iltalukion. Lasten saamisen vuoksi menetti työpaikkansa ja lopetti opiskelun. Sai kuitenkin lapsistaan voimaa ja aloitti jonkin ajan kuluttua iltalukion uudestaan. 0 piskelun ja perheen hoitaminen yhtä aikaa oli rankkaa: usein kello oli kaksi tai kolme yöllä kun pääsi nukkumaan. K irjoitti ylioppilaaksi ja penkkarit, kirjoitukset ja lakkiaiset olivat suuria kokemuksia. "E i parempaa päätöstä koko urakoinnille ollut kuin saada symbolinen valkoinen lakki - vihdoinkin!“ $N$ äin lukion jääminen ei enää hiertänyt mieltä. 0 nnistuminen muutti käsitystä itsestä oppijana ja nyt uskaltaa ottaa vastaan vaativampia haasteita. Vihjaa opiskelun jatkosuunnitelmista kertoessaan olevansa nyt tämän uuden luottamuksensa alkutaipaleella.

\section{Motiivisanastot kulttuurisina resursseina}

C. Wright Mills (1940) esittää käsitteen motiivisanasto (vocabularies of motive), jolla hän viit- ta kielessä käytössä oleviin kulttuurisiin ilmauksiin, jotka ovat inmisten käytettävissä toiminnassa sekä toiminnan perustelemisessa tai oikeuttamisessa. K lassisessa artikkelissaan Mills on jo varsin varhain omaksunut kielitieteestä internalistisen asennoitumistavan kielen käytön tarkasteluun. Sen sijaan, että kieltä käytettäisiin viittaamaan yksilöiden yksilöllisiin tiloihin, voidaan tarkastella kielen sosiaalisia funktioita. E i siis välttämättä tarvitse olla kiinnostunut jostakin kielen käyttöä edeltävästä, vaan voidaan olla kiinnostuneita myös esimerkiksi siitä miten tietynlainen kielen käyttö vaikuttaa tulevaan toimintaan. Tämä ajatus on sittemmin paljolti diskurssianalyysin myötä tullut tunnetuksi laajemminkin yhteiskuntatieteissä.

M ills (1940, 904-909) tarkastelee motiiveja tyypillisinä sanastoina, joilla tietyssä tilanteessa on tietty funktio. I hmisillä on tapana antaa omalle ja toistensa toiminnalle sanallinen perustelu. Y ksinkertaisesti "motiivit ovat sanoja". E rilaisissa tilanteissa on käytössä erilaiset motiivisanastot. $\mathrm{N}$ iinpä samakin toiminta voidaan eri tilanteissa perustella eri tavoilla - eri tilanteissa erilaiset motiivit ovat hyväksyttyjä. Motiiveilla voidaan perustella ja oikeuttaa yhtälailla tulevaa, nykyistä kuin mennyttäkin toimintaa. Mills kyseenalaistaa jaottelun "todellisiin" ja rationaalisiin motiiveihin. $\mathrm{H}$ än katsoo, että fysiologisia prosesseja ei voi päätellä kielellisistä ilmiöistä. Millsille kieli ei ole ulkoinen ilmaus tai myötäseuraus jostakin prioorisesta, aidosta ja syvällisestä yksilössä. Ei myöskään ole olemassa mitään tapaa varmistaa empiirisesti sisäisten prosessien ja kielellisten ilmauksien vastaavuutta. H enkilön ilmauksia tietyssä tilanteessa voidaan verrata ainoastaan hänen esittämiinsä ilmauksiin jossakin toisessa tilanteessa. $\mathrm{N}$ äiden mahdollinen yhdenmukaisuus ei kuitenkaan todista ilmauksien luotettavuutta sisäisten prosessien kuvauksena. Näin ollen verbalisoituja motiiveja ei tule käyttää kuvaamaan jotakin sellaista, mikä on inmisen omassa tietoisuudessa. Sen sijaan niitä voidaan käyttää kuvaamaan sitä, mitkä ovat tietyssä tilanteessa käytössä olevat motiivisanastot.

Seuraavassa tarkastelussa on noudatettu Millsin 
ajatusta motiiveista kulttuurisina ilmauksina, jolloin ne näyttäytyvät puhujan tai kirjoittajan käytettävissä olevina tapoina käyttää kieltä. Huomio on kiinnitetty opiskeluun yleensä tai jonkin tietyn alan valinnan perusteluihin. Samalla kun esitetyt ilmaukset kuvaavat kulttuurissa vallitsevia opiskelun perustelemisen tapoja, ne ovat osa henkilöiden identiteetin esittämistä. D iskursiivisessa tavassa lukea ja tulkita aineistoja on usein keskeisenä kysymys siitä, minkälaista identiteettiä henkilö puheellaan itselleen tai viiteryhmälleen rakentaa (esimerkiksi Honkonen 1997, 124-181). Tällöin ajatellaan Millsin tapaan, että kieli ei niinkään kuvaa todellisuutta, vaan luo sitä. Samaan tapaan identiteetin diskursiivinen rakentaminen tai esittäminen on usein esillä myös postmoderneissa identiteettikäsityksissä (esim. Gergen 1991; Bauman 1993; K ellner 1995).

O piskelijoiden opiskeluelämänkerroissa esiintyi suhteellisen runsaasti opiskelun perusteluja. Perustelujen avulla oma toiminta näyttäytyy järkevänä: ihmiselle on ominaista nähdä oma elämänsä narratiivina, jossa kertomuksen osat liittyvät loogisesti toisiinsa. K ertomuksen yksittäinen asia saa merkityksensä osana kokonaisuutta (Polkinghorne 1988, 19; Freeman 1992, 33). Tosin opiskeleminen oli ilmeisesti toisinaan niin itsestään selvä asia, että kirjoittaja ei ollut katsonut perusteiden esittämistä tarpeelliseksi. 0 piskelijoiden ilmaukset liittyvät toisaalta heidän omaan elämänkertomukseensa ja toisaalta siihen historialliseen aikaan, jossa tapahtumat on eletty ja kerrottu. E rilaisia perusteluja opiskelulle ylipäänsä tai opiskeltavan alan valinnalle esiintyi yhtätoista eri tyyppiä. K oska muut esitetyt perusteet ovat käytössä vain kerran taikka kaksi, voidaan vain seuraavassa taulukossa esiintyviä pitää toistuvina puhetapoina.

I tsestäänselvyys mainittiin pari kertaa, mutta opiskeleminen ja alan valinta vaikutti olevan sitä paljon useamminkin: henkilön kertomus saattoi olla koulutuksen kyllästämä, mutta perusteluja esitettiin vain muutamassa kohdassa ja silloinkin ohimennen.
Taulukko 1. O piskeluun liittyät motiivisanastot

Työelämään liittyvä opiskelu 19 äytössä kertaa
- reaktiivinen opiskelu (8 kertaa)
- ennakoiva opiskelu (11 kertaa)

2. Kiinnostus ja oma ilo 11

3. Aikaisempi elämä (, jolle opiskelu on luonnollista jatkoa)

6

4. Tulevat opinnot

4

5. Muut inmiset

\section{Työelämään liittyvä opiskelu}

Työhön liittyvät kuvaukset olivat aineistossa yleisin tapa perustella koulutusta. E simerkiksi yhteiskuntatieteiden kandidaatti, jonka koulutuselämänkertaa edellä luonnehdittiin määreellä 'Koulutus mielenkiinnon ja hyödyn sekoituksena' mainitsi useissa yhteyksissä työhön liittyvät tekijät opintojensa perusteluina vaikka hän toisaalta oli opiskellut asioita myös "puhtaasti“ kiinnostuksesta ja harrastusmielessä. Työn pohjalta virinnyttä sosiaalipolitiikan opiskelua hän perustelee seuraavasti:

“Jotenkin tuntui, että omaa tieämystään pitäisi lisätä sosiaalipditiikan suuntaan. Lisäksi siitä löytyisi mahdollisuus laajentaa ammatillista pätenyttä; tiettyjen opintojen jälk€n voisin saada sosiaalityöntekijän päteyyden. Jos tuo nyt mitään hyödyttäisi.“

Saman ajatuskulun, kyynistä loppukommenttia myöten, hän toistaa erityispedagogiikan opintojen perusteluissa:

"E rityispedagogikan appron suoritin kesäyliopistossa. Olen sen verran työskennellyt kehitysvammaisten kanssa mm lukumuoden opetustyössä, että tunsin sen jotenkin lähèseksi ja ajattein, että siitä vaisi tulevaisurdessa dla hyötyä. Ei vidä de ollut."

Hän hakeutui myös "A mmatiksi aikuiskoulutus" -työllisyyskoulutukseen ja perustelut noudattavat samaa rataa:

“Koulutus tuntui devan juuri minulle sopiva, dinhan jonkin verran tehnyt opetustyö- 


\section{ARाাKस्ता}

tä. Taivoin, että kurssi parantaisi tulevaisuut dessa mahddlisuuksiani opetustyöhön."

$\mathrm{N}$ ykyiset kasvatustieteen opinnot ovat kertomuksessa luonnollista jatkoa:

"Tämän hetkinen kasvatustieten opiskelu on enemmänkin hyätynäkökohdista kuin midenkiinnosta. Kuvitteen taas, että kas vatustieen d voi dla hyödylinen sitten joskus."

$N$ ämä kuvaukset kertovat karua kieltään nykyisestä historiallisesta ajasta. N uorille aikuisille akateeminen tutkinto ei enää takaa pysyvää työsuhdetta, vaan he parsivat elämänsä kokoon työttömyyden, Iyhyiden työsuhteiden ja opiskelun vuorottelusta. Toisinaan koulutukseen suhtaudutaan hieman epäillen, kuten tässä esimerkissä, toisinaan sitä pidetään varsin varmana vakuutuksena työttömyyttä vastaan. Työelämä "pakottaa" opiskelemaan ja työelämäpuhe oikeuttaa opiskelemisen silloin kun muut elämänalueet saattaisivat siitä kärsiä.

K äyttämällä "työelämäpuhetta" opiskelijat samalla luovat itselleen identiteetin vastuullisena kansalaisena, joka kantaa huolta ainakin omasta itsestään huolehtiessaan mahdollisuuksistaan työmarkkinoilla. Tällainen aktiivinen kansalainen epäilemättä onkin ideaalinen "elinikäisellä oppimisella työttömyyttä vastaan" -ideologian ilmentymä. Eri asia on se, että elinikäinen oppiminen ei tosiasiassa yhteiskunnan työttömyysongelmia ratkaise.

Työelämään liittyvät perustelut jakaantuvat yllättävän selvästi kahteen tapaan: reaktiiviseen ja ennakoivaan. Røktiivista työ elämään liittyvä koulutus on silloin kun henkilö hakeutuu koulutukseen työssä kokemansa riittämättömän pätevyyden vuoksi. E dellä kaksi ensimmäistä sitaattia olivat tätä tyyppiä; työssä saadun kokemuksen pohjalta henkilö katsoi, että tarvitsee lisäkoulutusta. 'O piskelu vastauksena työelämän haasteisiin' -tapauksessa tällainen opiskelu oli koko kertomuksen 'punainen lanka', jonka henkilö toi selkeästi esille käyttämällä ilmauksia: "Jonkin aikaa työtä tehtyäni tunsin tar-vitsevani lisäkoulutusta" ja "Olin siis taas epäpätevä. Siispä piti saada koulutusta“.

K ertomuksissa oli myös kuvauksia ennakaivas ta työelämään liittyvästä kouluttautumisesta. Tällöin ei reagoida osaamisen jo esiintulleisiin puutteisiin, vaan valmistaudutaan tulevaisuudessa mahdollisesti vastaan tuleviin vaatimuksiin ja parannetaan asemaa työmarkkinoilla keräilemällä koulutusta aloilta, joista mahdollisesti voisi olla hyötyä. H enkilöllä ei välttämättä ole selvää kuvaa siitä, tuleeko opiskeltavista asioista todella olemaan hyötyä työelämässä tai miten ja missä hän tulee oppiaan hyödyntämään. 'K oulutus mielenkiinnon ja hyödyn sekoituksena' -tapauksen käyttämä ilmaus "epämääräiset hyötynnäkökohdat" onkin kuvaava: asemaa työvoimajonossa pitää parantaa keräilemällä erilaisia koulutuksia, jotka jotenkin tuntuvat luontevilta omassa elämänkertomuksessa: "kasvatustieteen cum laude voi olla hyödyllinen sitten joskus". Toisinaan taas ennakoiva opiskelu voi tähdätä hyvinkin määrätietoisesti johonkin tiettyyn ammatilliseen tavoitteeseen.

\section{Kiinnostus ja oma ilo}

K iinnostus jotakin asiaa tai ylipäätään opiskelua kohtaan oli toiseksi yleisin tapa perustella koulutusta. Kirjoituksista löydettyjen motivisanastojen frekvensseistä poiketen keskusteluaineistossa opiskelijat kylläkin asettavat ensisijaiseksi yhteiseksi piirteekseen halun opiskella. K iinnostuksen ilmauksissa kirjoituksissa kerrotaan yleisestä kiinnostuksesta avoimen yliopiston opiskeluun ja omaehtoiseen opiskeluun, yliopiston pää- ja sivuaineiden valinnasta kiinnostuksen mukaan, sekä harrastusluonteisista kursseista esim. kansalaisopistossa. U sein kiinnostus on yhteydessä työelämään, joten työelämäpuhe ja kiinnostuspuhe eivät ole toisensa poissulkevia luokkia vaan usein läheisesti toisiinsa liittyviä. Ulkoiset pakot ja oma kiinnostus kietoutuvat yhteen niin, että on vaikea määritellä kumpi loppujen lopuksi olisi jotenkin perimmäisempää.

"Tässä vaiheessa ajattein tulevaisuutta siltä kannalta, etä vaikka minulla di opistoasteen tutkinto, mitä muillakin tuhansilla in- 
misillä on, niin minulla disi tarjoła jđain sellaista tieca ja taitoa, mitä muilta saman alan ihmisiltä puuttui. Kilpailutilanne työdämässä sai minut opiskelemaan lisää. Myös halu tieää lisää asioista sai minut opiskde maan." (koulutus riippumutena)

"A siat kiinnostavat, koska mutosta on tapahtunut niin paljon. Tunnen saavani "eväitä“ tyätäni varten." (koulutus vastauksena työdämän haastesiin)

K eskusteluaineistossa työelämäpuhe ja kiinnostuspuhe myös eriytyvät toisinaan ja näyttäytyvät jopa vastakkaisina.

"Niin ja se, ettè tarvite tendä sitä työä, vaan saa tehdä mitä itse haluaa."

"....ttä jos vais opiskella siihen saakka maksettas joku opiskdueäke - niin se dis ihan mukava tulevaisuudenkuva."

$\mathrm{K}$ iinnostuspuhe on individualistinen tapa ilmaista asioita. Puhuttaessa kiinnostuksesta viitataan yksilön sisäiseen suuntautuneisuuteen. H enkilön toimintaa eivät tällöin sanele ulkopuoliset ehdot, vaan hän toimii omista lähtökohdistaan. Myös puhe "omaksi iloksi" opiskelemisesta kuuluu tähän samaan luokkaan. Kiinnostuspuhetta käyttäessään henkilöt samalla luovat itselleen itseohjautuvan opiskelijan identiteetin; henkilö ei ole ulkoisten pakkojen marionetti. K eskusteluaineistossa opiskelijat myös itse pohtivat, onko kouluttautuminen heistä itsestään lähtevää ja toisaalta missä määrin ulkopuoliset ehdot ovat säädelleet heidän toimintaansa.

\section{Aikaisempi elämä}

Aikaisemman elämän toiminnalla tai tapahtumilla perusteleminen on luonteva narratiivinen strategia perustella toimiaan. V iittaaminen siihen mitä aiemmin teki, tehdään jostakin teosta elimellinen, luonnollinen osa kronologista kertomusta. Mielen aikaansaaminen omaan toimintaan on yksi kertomusten funktio (McCall \& Wittner 1990, 59).

“Paikkakunnallemme di tullut mutamia uosia aiemmin tekstilitendas. Olin ollut sielä kesätässä ja suunnittdin kovasti tekstiili-insinörin uraa." (koulutus vastaukse na työdämän haasteisiin)

“Miksi juuri kauppaopistoon? Tässä vaiheessa din dlut pankissa töissä ja din innostur nut työskentelemään sielä jatkossakin. $\mathrm{Ha}$ lusin tieää lisää taloudesta ja kaupallisista menettytavoista." (koulutus riippumur tena)

"Koulutus tuntui juuri minulle sopivalta, dinhan jonkin verran tehnyt opetustyötä." (koulutus midenkiinnon ja hyödyn sekaituksena)

A rkikielessä kertomus on luonteva tapa tehdä omista toimista ja valinnoista järkeviä ja perusteltuja: "olin ollut pankissa töissä ja..." Elämänkerrallinen menetelmä kykenee tuottamaan tällaisia narratiivisia tulkintoja tapahtumista. K uten näistäkin otteista huomataan, inmisen toiminnan perustelut "sijaitsevat" sekä menneessä että tulevassa. $\mathrm{K}$ un elämänkertomuksen palaset sopivat loogisesti yhteen muodostaa henkilö itselleen identiteetin järkevänä ja johdonmukaisena ihmisenä. A ikaisempien tapahtumien, sen hetkisen itsetuntemuksen ja tulevaisuuden suunnitelmien valossa ratkaisut tällaisessa loogisessa kertomuksessa näyttäytyvät järkeviltä. $\mathrm{N}$ äin on silti, vaikka henkilö jälkikäteen toteaisi tehneensä esimerkiksi koulutus- tai ammattivalinnoissaan virheratkaisuja.

\section{Tulevat opinnot}

K oulutusta perusteltiin myös tulevilla opinnoilla. K oulutusyhteiskunnassa tietty koulutus on vaatimuksena johonkin toiseen tai ainakin siitä voi olla etua koulutusmarkkinoilla taistelussa niukoista koulutuspaikoista. Vaikka kaikki eivät suoraan puhu koulutuksesta tulevien opintojen perustana, on kaikkien kertomusten Iopussa tavalla tai toisella tällainen ajatuskulku. Jokainen kirjoittaja vähintäänkin mainitsee tulevat opiskelusuunnitelmansa. $\mathrm{N}$ äin nykyinen kasvatustieteen opiskelu asettuu, ei aluksi eikä lopuksi, vaan yhdeksi lenkiksi koulutuksen ketjussa. Juuri avoin yliopisto, josta aineisto on kerätty, toimii tällaisena linkkinä. Joka tapa- 
uksessa koulutuselämänkerrat ovat ilmentymä kulttuurisesta kertomuksesta, jossa päähenkilö vastoinkäymisistä välittämättä kamppailee luontoa vastaan. K orven tai suon raivaaja vain on vaihtunut työ- ja koulutusmarkkinoilla kamppailevaan itsensä kehittäjään. Taistelu Iuonnonvoimia vastaan on vaihtunut kilpajuoksuksi työelämän muutoksien kanssa.

K oulutusta perusteltaessa tulevilla opinnoilla luodaan hyvin samankaltaista identiteettiä hyvin samankaltaisella diskursiivisella strategialla kuin tapahtui viitattaessa elämän menneisiin tapahtumiin. Tässäkin ihminen näyttäytyy järkevänä ja johdonmukaisena ja lisäksi vielä määrätietoisena elämänsä ohjaajana.

\section{Muut ihmiset}

Muut ihmiset olivat kavereita, poikaystäviä, opettajia, joilla oli henkilöiden kertoman mukaan vaikutusta opiskelun aloittamiseen tai suuntautuneisuuteen. Puhe muista inmisistä on vastakkaista erityisesti kiinnostuspuheelle sikäli, että kun kiinnostuspuhe luo henkilöstä kuvan itseohjautuvana, puhe muiden ihmisten vaikutuksesta luo hänelle toisten vaikutuksille alttiin toimijan identiteetin. Puhetavat eivät kuitenkaan sulje toisiaan pois, vaan ne voivat esiintyä samankin kertomuksen eri yhteyksissä.

\section{Aikuiskoulutus ja tulevaisuuteen suuntautuminen}

Aiemmin sosialisaation katsottiin rajautuvan lapsuuteen ja nuoruuteen, joita elämänvaiheina Iuonnehti valmistautuminen aikuisuutta varten. Toki lapsuus ja nuoruus ovat tätä edelleenkin. Kuitenkin, kuten koulutukseen liittyvien motiivisanastojen tarkastelu osoitti, myös aikuisuutta luonnehtivat nykyisin aiemmin pelkästään lapsuuteen ja nuoruuteen liitetyt määreet: keskeneräisyys, riittämättömyys, puutteellisuus ja - työelämän muutosten myötä yhä useammin epävarmuus ja avoimuus vaihtoehdoille. K oulutuksen perusteluissa työelämän merkitys dominoi. O piskelua perustellaan usein myös opis- kelulla itsellään; opiskeleminen parantaa paitsi työmahdollisuuksia, myös tulevia opiskelumahdollisuuksia. Samalla opiskelijoille on ollut tärkeää (keskusteluaineisto) löytää narratiivinsa rakentamisessa koulutukseen hakeutumisensa motiiviksi "oma mielenkiinto": oman toimintansa ymmärtämiseen pyrkiessä haetaan tasapainoa yhteiskunnallisten tekijöiden ja henkilökohtaisen merkityksenantojen välille.

Juuri näiden kahden keskenään selväsi ristiriitaisen ulottuvuuden (ulkoinen pakko vs. oma kiinnostus) yhteenkietoutuminen ja erityisesti sopusointu henkilöiden puheessa on merkillepantavaa. Toisaalla työelämäpuheen sekä toisaalla kiinnostuksen ja oman ilon esiintyminen ei sinänsä ole kovin yllättävää, onhan länsimainen koulutus selvästi näiden kahden arvon taistelukenttä. K ulttuurissamme arvostetaan aineellista hyötyä tuottavaa osaamista, joka ilmenee erityisesti tavaroiden ja palvelusten tuottamisena työelämässä. Toisaalta Platonin ajatus tietämisestä tietämisen itsensä vuoksi taikka ajatus oppimisen ilosta arvona sinänsä, elävät myös vahvasti niin kansalaisten kuin koko aikuiskasvatusjärjestelmänkin arvomaailmoissa.

Aikuiskoulutuksen suurkuluttajien aikuisuutta luonnehtiikin piirre, joka tavallisesti on annettu nuoruudelle. Nuoruus mielletään usein Tommi Hoikkalan $(1993,148)$ ilmaisua käyttääksemme - kouluttautumiseksi ja itsenäisyyden ainesten hankkimiseksi tulevaisuudessa sijaitsevaa varten. Tietyt aineiston ilmaukset viittaavat siihen, että koulutus on usein pyrkimystä pitää mahdollisuuksia avoimena:

"Tavitteena on ala-asteen luokanopettajan pätenys ja siitä enkä joskus, jos siltä tuntuu, takaisin siihen lempiaineeseen di äidinkiden..."

"Haaveena on kuitenkin jatkossa, että vai tehdä juuri sitä tyätä, jota haluaa tehdä..." "Tulevaisuus on onneksi avoin ... J ospa sattuma taas astuu kunaan. En toddlakaan de vieä valmis asettautuman laakerélleni ja odottamaan hyin ansaittua däkettä, vaikka denkin dlut yhtäjaksoisesti työdämäs sä kaksikymmentäseitsemän vudta..." 
"Olen hyvin optimistinen tuleaisuuden suhteen. Jos motivaationi kestää sekä perheøni suvaitsee ja jaksaa, niin aion opiskella vidä monta vuotta."

Vaihtoehtojen avoimuus ja oma keskeneräisyys eivät näissä otteissa näyttäydy mitenkään ahdistavina ja negatiivisina asioina. A ikuisuus, joka määrittyy "valmiina" ja vakiintumisena, saattaa pikemminkin olla monille negatiivinen asia. K uten Hoikkala $(1993,241)$ toteaa kuvatessaan yhtä kulttuurissamme esiintyvää aikuisuuskäsitystä: "Jos nuoruuden teot ilmentävät liikettä ja muutosta, niin aikuisuuden teot ilmentävät staattisuutta, vakiintuneisuutta, jopa pysähdystä." H än jatkaa, että usein, varsinkin naisiin liittyvissä ilmauksissa tällainen pysähtynyt jämähdys halutaan torjua. Hoikkalan aineiston "ylpeä yksinhuoltaja" toteaa, ettei hän koskaan halua aikuistua: "Elämä loppuu ja tylsyys alkaa siinä vaiheessa kun aikuistuu." Tämän ilmiön sisältö näyttäytyy myös tämän tutkimuksen keskusteluaineistossa; keskusteluissa todetaan, että on hyvä olla jatkuvasti "tavoite tähtäimessä", "seuraava porras". Samassa yhteydessä yksi opiskelija esittää kysymyksen siitä, onko toiminnan taustalla pelko "paikalleen jäämisestä".

Tutkimillemme inmisille elämä on ollut ja tulee olemaan opiskelua. Avoimen yliopiston opiskelijoina he jo sinällään edustavat väestön osaa, joka aktiivisesti kehittää itseään koulutuksen avulla. He ovat sinuja jatkuvan koulutuksen idean ja keskeneräisenä avointen mahdollisuuksien edessä olemisen kanssa. N yyssölän (1994) mukaan nuorilla työttömillä koulutus korvaa työhön liittyneitä sisällöllisiä ja sosiaalisia merkityksiä ja yhtäaikaisesti nuoret uskovat vahvasti koulutuksen avaavan mahdollisuuksia työmarkkinoille. N uorten suhde työntekoon on jossain määrin instrumentaalista, mikä osittain selittyy työmahdollisuuksien puutteella. A ineistomme edustaa hieman vanhempaa sukupolvea. Työlle asetetaan kyllä korkeitakin sisällöllisiä odotuksia, mutta työn puuttumisen mahdollisuutta sovitetaan oman elämän suunnitelmissa koulutusta arvostavilla merkityksenannoilla. Suhde koulutukseen on samansuuntainen kuin nuorilla työttömillä, mutta samalla kriittisempi. "Elinikäisen oppijan mallinarratiiveissa" ongelmana on, että niiden käsikirjoituksen läpieläminen ei viehätä kaikkia. Samoin, vaikka merkittävät teoriat inmisen kasvusta näkevätkin inmisen keskeneräisenä läpi elämän (kts. Autio 1991,193), monet saattavat kokea ahdistavana elinikäisen oppimisen ideaan liittyvän ajatuksen jatkuvasta riittämättömyydestä, keskeneräisyydestä tai keskenkasvuisuudesta. Elinikäisten oppijoiden elämänkertomukset ovat kiistatta myönteisiä kuvatessaan aikuisten halua kouluttautua ja kehittyä, mutta myönteisyyden näkyminen laajemmin ihmisten elämänkertomuksissa edellyttänee, että ko. kertomuksissa esiintyvästä elämänasenteesta ei tehdä normia jokaiselle kansalaiselle!

\section{Lähteet}

ALHEIT, P., Bron-Wojciechowska, A., Brugger, E. \& Dominicé, P. 1995. The Biographical Approach in European Adult Education. Verband Wiener Volksbildung.

ANTIKAINEN, A. \& Huotelin, H. (toim.) 1996. Oppiminen ja dämänhistoria. Aikuiskasvatuksen 37. vuosikirja. K ansanvalistusseura ja A ikuiskasvatuksen tutkimusseura.

ANTIKAINEN, A., Houtsonen, J. Huotelin, H.\& Kauppila, J. (1996). Living in a Learning Sodey. LifeHistories, Identities and Education. London: The Falmer Press.

AUTIO, T. 1991. Some Aspects Concerning the Concept of Lifelong Education. Teoksessa Raivola, R. \& Ropo, E. (toim.) Jatkuva koulutus ja dinikäinen oppiminen. XII K asvatustieteen päivät Tampereella 22.-24.11.1990. Tampereen yliopiston kasvatustieteen laitos A 49.

BAUMAN, Z. 1993 (1992). Intimations of Postmodernity. London: Routledge.

BERTAUX D. \& Kohli, M. 1984. The Life Story Approach: A Continental View. Annual Review of Soidogy 10, 215-237.

BERTA UX D. 1983 (1981). Introduction. Teoksessa Bertaux D. (toim.), Biogaphy and Sociey. The Life History A pproach in the Social Sciences. Sage Studies in International Sociology 23. Beverly Hills: Sage, 5-11.

DOMINICĖ, P. 1995. Composing Education Biographies: Group Reflection Through Life $\mathrm{H}$ is- 
tories. Teoksessa Mezirow J. and Associates, Fostering Critical Reflection in Adulthood. A Guide to Transformative and Emancipatory Learning. 0 xford: Jossey-B ass Publishers.

FREEMAN, M. 1992. Self as N arrative: The Place of Life History in Studying the Life Span. In B rinthaupt, T.M . \& Lipka, R.P. (eds.), The Seff. D efinitional and Methodological I ssues. Albany: State University of $\mathrm{N}$ ew York Press, 15-43.

GERGEN, K.J. \& Gergen, M.M. 1988. N arrative and the Self as Relationship. Advances in Experimental Social Psychdogy 21, 17-55.

GERGE N , K .J. 1991. The Saturated Self. Dilemmas of I dentity in Contemporary Life Basic Books.

H O IKKALA, T. 1993. Katoaako kasvatus, himme nekö aikuisuus? Aikuistumisen puhe ja kulttuurimallit. Jyväskylä: G audeamus.

HONKONEN, R. 1997. Best or Second Best Chace? Polytechnic Education in the Lives of Engineering Students. A cta Universitatis Tamperensis 546. Tampere: U niversity of Tampere.

JU SSILA, J. 1992. K valitatiivista ja kvantitatiivista tutkimusta koskeva kiista ja kasvatustieteen kriisi. Kasvatus 23 (3), 247-255.

KELLNER，D. 1995. Media Culture Cultural Studies, Identity and Politics between the Modern and the Postmodern. London and $\mathrm{N}$ ew York: Routledge.

K N UDSEN, J.C. 1990. Cognitive Models in Life Histories. Anthropdogical Quarterly 63 (3), $122-133$.

KOHLI, M. 1983 (1981). Biography: Account, Text, Method. Teoksessa Bertaux D. (toim.), Biography and Sociey. The Life H istory Approach in the Social Sciences. Sage Studies in International Sociology 23. Beverly Hills: Sage.

LIN N AK Y LÄ, P., M attinen, E.\& Olkinuora, A. 1988. Prosessikirjaittamisen opas. K euruu: 0 tava.

LIN DRO OS, M. 1995. Feministinen pedagogiikka. Kasvatus 26 (4), 331-339.

MCCALL, M.M. \& Wittner, J. 1990. The Good $\mathrm{N}$ ews about Life H istory. Teoksessa Becker, H.S. \& McCall, M.M. (toim.), Symbolic Interadion and Cultural Studes Chicago, London: The University of Chicago Press, 46-89.

MCCALL, M.M. 1985. Life History and Social Change. Studies in Symbolic Interadion 6, 169182.

MEYER, J.W. 1986. The Self and The Life Course: Institutionalization and I ts E ffects. Teoksessa Sørensen, A.B., Weinert, F.E. \& Sherrod, L.R. (toim.) Human Development and the Life Course Multidisciplinary Perspectives. Hillsdale
\& London: Lawrence Erlbaum Associates. 199216.

MILLS, C.W. 1940. Situated Actions and Vocabularies of Motive. A merican Socidogical Review 5, 904-913.

NIEMINEN , H. 1990. Aikuisopiskedu naisen dämänkdkonaisuudessa, opiskeluun liittyät motiivit ja niiden muttuminen. A ikuis- ja nuorisokasvatuksen laitoksen julkaisuja 26. Tampereen yliopisto.

N Y Y SSÖ LÄ, K . 1994. N uorten työttömien suhtautuminen koulutukseen ja työhön. Kasvatus 25 (4), 384-394.

PALLAS, A. M. 1993. Schooling in the Course of Human Lives: The Social Context of Education and the Transition to Adulthood in Industrial Society. Review of Educational Research 63 (4), 409-447.

POLKING HORNE, D.E. 1988. N arrative Knowing and the Human Sciences. Albany: State University of $\mathrm{N}$ ew York Press.

TIGERSTEDT, C. 1984. N är det tänkta skrivs och det skrivna tolkas. Ett experiment med självbiografier. Sosidoga 21 (1), 15-25.

TY N JÄLÄ, P. 1996. Kirjoittaminen oppimisen välineenä korkeakoulutuksessa. Kasvatus 27 (5), 425-438.

VILKKO, A. 1988. Eletty elämä, kerrottu elämä, tarinoitunut elämä - omaelämäkerta ja yhteisymmärrys. Sosidogia 2, 81-90.

\section{Viite}

1. K iitämme tutkimukseen osallistuneita opiskelijoita tutkimushenkilöinä toimimisesta ja myönteisestä suhtautumisesta opiskelun ja tutkimuksen yhdistämiseen. K iitämme myös yhden harjoitusryhmän opettajana toiminutta Anne Lahtista avusta projektin toteuttamisessa ja Anneli Tunkkaria nauhalla olleen aineiston purkamisesta.

Artikkeli saapui toimitukseen 1.4.1997. Toimituskunta teki siitä julkaisupäätöksen 12.1.1998. 